\title{
Ground Glass Pozzolan in Conventional, High, and Ultra-High Performance Concrete
}

\author{
Arezki Tagnit-Hamou ${ }^{1}$, Ablam Zidol ${ }^{1}$, Nancy Soliman ${ }^{1}$ Joris Deschamps ${ }^{1}$, and Ahmed Omran ${ }^{1}$ \\ ${ }^{1}$ Department of civil Engineering, University of Sherbrooke, Sherbrooke (QC) Canada
}

\begin{abstract}
Ground-glass pozzolan (G) obtained by grinding the mixed-waste glass to same fineness of cement can act as a supplementary-cementitious material (SCM), given that it is an amorphous and a pozzolanic material. The $\mathrm{G}$ showed promising performances in different concrete types such as conventional concrete (CC), high-performance concrete (HPC), and ultra-high performance concrete (UHPC). The current paper reports on the characteristics and performance of $\mathrm{G}$ in these concrete types. The use of $\mathrm{G}$ provides several advantages (technological, economical, and environmental). It reduces the production cost of concrete and decrease the carbon footprint of a traditional concrete structures. The rheology of fresh concrete can be improved due to the replacement of cement by non-absorptive glass particles. Strength and rigidity improvements in the concrete containing $\mathrm{G}$ are due to the fact that glass particles act as inclusions having a very high strength and elastic modulus that have a strengthening effect on the overall hardened matrix.

Keywords: Ground-glass pozzolan (G), Durability characteristics, Fresh properties, Mechanical performance, conventional concrete, high-performance concrete, and ultra-high performance concrete.
\end{abstract}

\section{Introduction}

The use of supplementary-cementitious materials (SCMs) can help cement-based material construction achieving sustainable development by reducing cement production and therefore reduce fossil-fuel consumption and greenhouse-gas emissions. Alternative locally available SCMs are favorable when traditional SCMs are not locally available or costly if transported. Concrete industry is currently seeking additional sources of SCMs to supplement fly ash, slag cement, and silica fume that are currently used in concrete.

There are several million tons of recycled glass available and are widely dispersed across the globe. The groundglass pozzolan $(\mathrm{G})$ obtained by grinding the mixed-waste glass to same fineness of cement can act as an SCM, especially it is amorphous and pozzolanic material. The mixed colored waste glass cannot be recycled and in the best scenarios, is stockpiled, causing obvious environmental and economic problems. Therefore, valorization of this waste glass as an SCM could provide dual advantages. Over decades, the $\mathrm{G}$ showed promising performance in mortar and concrete mixtures both in laboratory and in large-scale field applications with more focus on long-term performance.

The purpose of this paper is to summarize material specifications for the $G$ for use as a pozzolan as a partial replacement of portland cement in concrete. The overall performance (fresh, mechanical, durability, and life-cycle assessment) of incorporating $\mathrm{G}$ in cement-based materials (CC, HPC, and UHPC) in both laboratory and field applications are highlighted in this paper.

\section{$2 \mathrm{CC}$ and HPC containing $\mathrm{G}$}

\subsection{Mix design and fresh properties}

This section of the paper focuses on the performance of the $\mathrm{G}$ in two types of concrete: CC and HPC. The CC is a concrete with water-to-binder ratio $(w / b)$ of 0.55 or 0.42 with respective binder content of 350 and $390 \mathrm{~kg} / \mathrm{m}^{3}$. The HPC is a concrete with a $w / b$ of 0.30 with relatively higher binder content of $460 \mathrm{~kg} / \mathrm{m}^{3}$. The slump value of the $\mathrm{CC}$ is in the range of $\pm 110 \mathrm{~mm}$ and that for the HPC is about $\pm 210 \mathrm{~mm}$. The air contents of the two types of concrete varied between $4 \%$ and $8 \%$. These two types of concretes can contain different rates of $G$ in partial substitution of cement.

\subsection{Compressive Strength}

Figure 1 shows the compressive strength $\left(f_{c}^{\prime}\right)$ of the $\mathrm{CC}$ (Fig. 1-a) and HPC (Fig. 1-b) concrete types. Of course, the HPC presented higher $f_{c}^{\prime}$ than CC due to the effect of its low $w / b$. Whether in CC or HPC, the $f_{c}^{\prime}$ of concrete mixtures incorporating $\mathrm{G}$ are low at an early age but increase significantly in the long term. Similarly to the 
typical pozzolanic materials, the $\mathrm{G}$ concretes have lower $f_{c}^{\prime}$ (about $12 \%$ ) than the control at early age (less than 91 days), but they develop greater $f_{c}^{\prime}$ than the control (about $18 \%$ ) at long-term (beyond the 91 days). The low earlyage $f_{c}^{\prime}$ results from the dilution effect and the slow reactivity of the $\mathrm{G}$. The improvement of the long-term $f_{c}^{\prime}$ results is due the pozzolanic activity of the $G[1,2]$.

\subsection{Chloride-Ion Permeability}

The results of the chloride-ion permeability of the $\mathrm{CC}$ at 28 and 91 days are shown in Fig. (2-a) while the results at 28 and 56 days for the HPC are presented in Fig. (2-b). The incorporation of the $G$ considerably reduces the permeability in both types of concrete. However, the reduction in the $\mathrm{CC}$ is even greater with time than that in the HPC. The reduction is not noticeable enough at 28 days due to the slow reactivity of the G. I the CC, at 91 days, the $\mathrm{G}$ reduces the permeability by $75 \%$ or even $80 \%$ depending on the rate of replacement. The corresponding reduction in the HPC is about one third. The effect of $\mathrm{G}$ is particularly interesting in the $\mathrm{CC}$ by its significant role in the reduction of permeability. Indeed, the $\mathrm{CC}$ containing $\mathrm{G}$ with a $w / b$ as high as 0.55 showed larger reduction in the permeability relative to that with a low $w / b$ of 0.30 . This demonstrates a greater contribution of the $\mathrm{G}$ in decreasing the permeability than a simple reduction in the water content or $w / b$. This important decrease in permeability in the presence of $G$ results from its pozzolanic reaction, which consumes large portlandite crystals to produce additional C-S-H that fills the pores in the microstructure level [3-6]. It is the refining effect of the pores and the grains, which generates an increased tortuosity of the pores reflecting the decrease of the permeability.
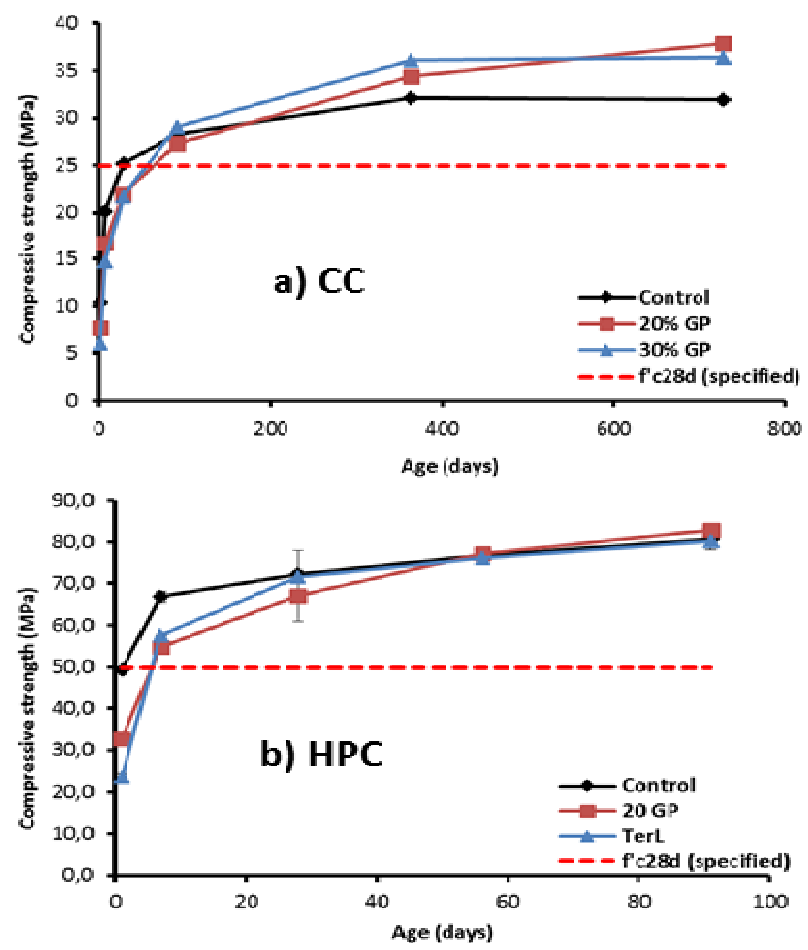

Fig. 1 Development of compressive strength with time for $\mathbf{G}$ concrete a) $C C$ with $w / b=0.55$, and b) HPC with $w / b=0.30$

\subsection{Scaling resistance}

Figure 3 shows the scaling resistance of the two types of concretes (CC and HPC). For all concrete mixtures containing or not $\mathrm{G}$, the results of the mass losses versus the de-icing scaling cycles are lower than the BNQ 2621905 standard limits demonstrating good resistance to scaling. However, the concrete mixtures containing $G$ exhibited mass losses slightly greater than those of the control concrete. It is a usual trend observed for the supplementary cementitious materials that seem more susceptible to scaling [7]. The $\mathrm{CC}$ usually have mass losses about four times higher than those of the HPC due to the low $w / b$ of the latter. Since the low $w / b$ would reduce excessive bleeding likely to weaken the skin of the concrete and makes it more vulnerable to scaling.

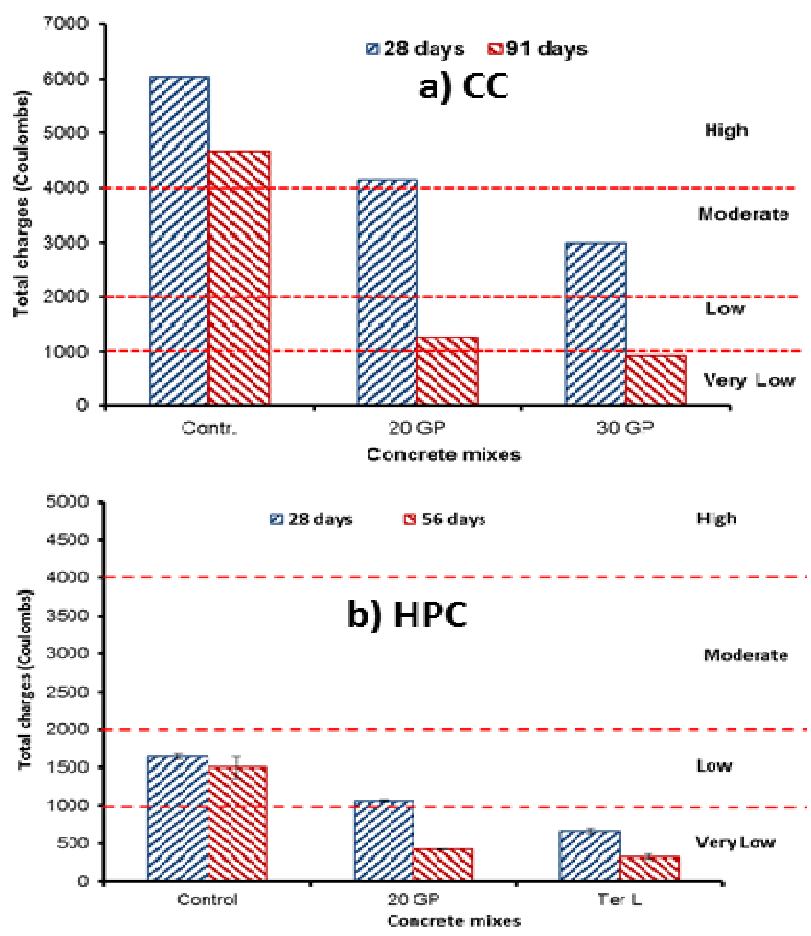

Fig. 2 Chloride-ion permeability of a) $C C$ with $w / b=0.55$, and b) $\mathrm{HPC}$ with $w / \mathrm{b}=0.30$ 

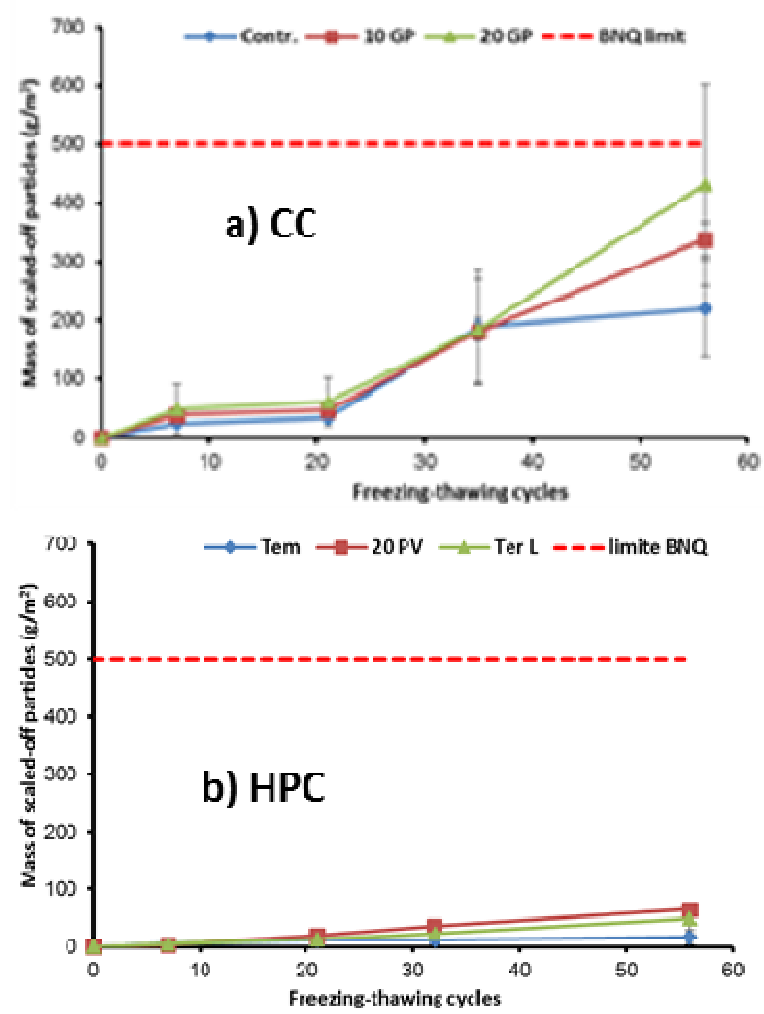

Fig. 3 Scaling resistance of a) CC with $w / b=0.42$, and b) HPC with $w / b=0.30$

\subsection{Drying shrinkage}

Figure 4 shows the drying shrinkage of the two types of concretes. Whether in CC or HPCs, the mixtures containing $\mathrm{G}$ exhibit a drying shrinkage similar to that of the control, suggesting that the $G$ does not enlarge the drying shrinkage of the concrete. The drying shrinkage of the HPC is very low, about one third of that of the CC, due to its low $w / b$ that limits the evaporation of free water and correlatively the drying shrinkage. Shayan et al. [8] also reported similar trends. These results suggest that the $\mathrm{G}$ concrete may have less or similar deformation and lower risk of cracking due to drying shrinkage than a control.
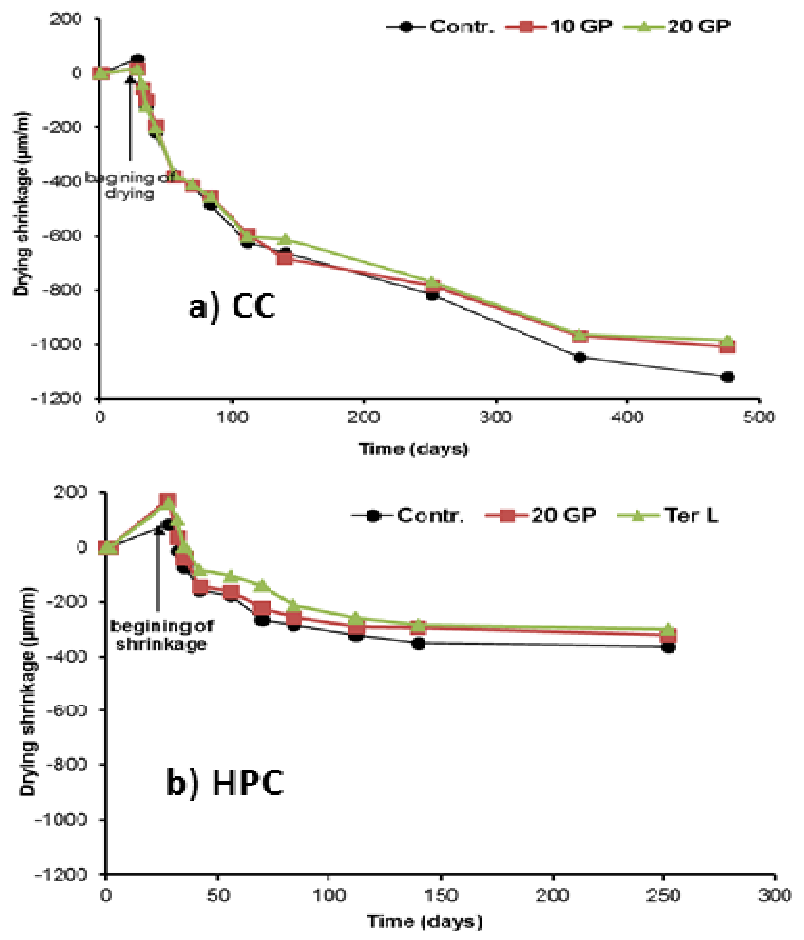

Fig. 4 Drying shrinkage of a) CC with $w / b=0.42$, and b) HPC with $w / b=0.30$

\section{Use of $G$ in UHPGC}

\subsection{UHPGC classes}

Based on the research conducted to develop UHPGC using waste-glass materials $[9,10]$, four different UHPGC classes can be delimited in responding to various construction demands (Table 1). The UHPC mixtures in Class A are characterized by low flowability (using minislump flow table) of less than $200 \mathrm{~mm}$ but with 2-day $f_{c}^{\prime}$ under hot curing conditions (HC) of more than $200 \mathrm{MPa}$. Concrete mixes in Class A have a $w / b$ between 0.150 and 0.190 . Highly flowable UHPGC can be obtained, as in Class C, with higher $w / b$ between 0.225 and 0.250 . The UHPGC mixtures in Class $\mathrm{C}$ are characterized by 2-day $f_{c}^{\prime}$ under HC between 160 and $175 \mathrm{MPa}$. The UHPGC mixtures in Class B blend the characteristics of those in Classes A and C. All UHPGC mixtures in Classes A, B, and $C$ are designed with steel fibers. The mixtures in Class D are designed for architectural applications, with the steel fiber replaced by polyvinyl alcohol fiber (PVA). The concretes in this Class D are characterized by higher flowability $(260 \mathrm{~mm})$ and moderate strength [91-day $f_{c}^{\prime}$ of more than $120 \mathrm{MPa}$ under normal curing conditions (NC)].

Table 1 UHPC with local materials for various construction applications

\begin{tabular}{|l|l|l|l|l|}
\hline Characteristics & Class A & Class B & Class C & Class D \\
\hline Flowability & $\begin{array}{l}\text { Semi- } \\
\text { flowable }\end{array}$ & Flowable & $\begin{array}{l}\text { Highly } \\
\text { flowable }\end{array}$ & $\begin{array}{l}\text { Highly } \\
\text { flowable }\end{array}$ \\
\hline $\begin{array}{l}\text { Average mini-slump } \\
\text { flow diameter, mm }\end{array}$ & 200 & 230 & 260 & 260 \\
\hline$w / b$ & $\begin{array}{l}0.150- \\
0.190\end{array}$ & $\begin{array}{l}0.190- \\
0.225\end{array}$ & $\begin{array}{l}0.225- \\
0.250\end{array}$ & $\begin{array}{l}0.225- \\
0.250\end{array}$ \\
\hline
\end{tabular}




\begin{tabular}{|l|l|l|l|l|}
\hline $\begin{array}{l}\text { \% of solids in } \\
\text { superplasticizer/cemen } \\
\text { t weight }\end{array}$ & $1-3$ & $1-3$ & $1-3$ & $0.225-0.25$ \\
\hline Steel fiber (\%) & 2 & 2 & 2 & -- \\
\hline PVA fiber & -- & -- & -- & 2.5 \\
\hline 2-day-HC f'c, MPa & $>200$ & $175-200$ & $160-175$ & -- \\
\hline 28-day-NC f'c, MPa & $>160$ & $>140$ & $>130$ & $>100$ \\
\hline 91-day-NC f'c, MPa & $>180$ & $>150$ & $>140$ & $>120$ \\
\hline Flexural strength, MPa & $>25$ & $>20$ & $>15$ & $>10$ \\
\hline $\begin{array}{l}\text { Modulus of elasticity, } \\
\text { GPa }\end{array}$ & $>50$ & $>45$ & $>40$ & $>40$ \\
\hline $\begin{array}{l}\text { Chloride-ion } \\
\text { penetration }\end{array}$ & $\begin{array}{l}\text { Negligibl } \\
\text { e }\end{array}$ & $\begin{array}{l}\text { Negligibl } \\
\mathrm{e}\end{array}$ & $\begin{array}{l}\text { Negligibl } \\
\mathrm{e}\end{array}$ & Negligible \\
\hline $\begin{array}{l}\text { Relative dynamic } \\
\text { modulus of elasticity } \\
\text { after 1000 freeze-thaw } \\
\text { cycles }\end{array}$ & $100 \%$ & $100 \%$ & $100 \%$ & $100 \%$ \\
\hline
\end{tabular}

\subsection{Material properties and mixture proportion}

Type high sulfate-resistance (HS) cement formulated with a low $\mathrm{C}_{3} \mathrm{~A}$ content was selected.. Silica fume (SF) conforming the CSA A3000 Standards "Cementitious materials compendium", and three ground-glass pozzolans ground to different sizes [G, fine $\mathrm{G}$ (FGP), and glass sand (GS)] with same $\mathrm{Na}_{2} \mathrm{O}_{\text {eq }}$ of $13 \%$ were used in the UHPGC mix designs. Table 2 provides the properties of these materials. This mixture had more than $400 \mathrm{~kg} / \mathrm{m}^{3}$ of $\mathrm{G}$ as cement replacement. A polycarboxylate-based HRWRA with a specific gravity of 1.09 and solid content of $40 \%$ was used. The PVA used were $13 \mathrm{~mm}$ in length and $0.2 \mathrm{~mm}$ in diameter, and had a specific gravity of 1.3 and tensile strength of $400 \mathrm{MPa}$.

\section{Table 2 Material properties}

\begin{tabular}{|l|c|c|c|c|c|c|}
\hline Property & $\begin{array}{c}\text { HS } \\
\text { Cement }\end{array}$ & $\begin{array}{c}\text { Silica } \\
\text { Fume }\end{array}$ & G & Fine G & $\begin{array}{c}\text { Glass } \\
\text { Sand }\end{array}$ & $\begin{array}{c}\text { Quartz } \\
\text { Sand }\end{array}$ \\
\hline Silica, \% & -- & 99.8 & 73 & 73 & 73 & 99.8 \\
\hline $\begin{array}{l}\text { Specific } \\
\text { gravity }\end{array}$ & 3.21 & 2.20 & 2.60 & 2.60 & 2.60 & 2.70 \\
\hline$d_{\max }, \mu \mathrm{m}$ & $<100$ & $<1$ & $<100$ & $<10$ & $<800$ & $<600$ \\
\hline
\end{tabular}

Table 3 presents the mixture proportions for seven UHPGC mixtures covering the various concrete Classes described in Table 1. A $2 \%$ volume fraction of steel fiber was used for UHPGC-1 to 6 mixtures, while $2.5 \%$ PVA fiber was used for UHPGC-7 mixture. As shown in Table 3 , the design allowed using $\mathrm{G}$ in all mixes in contents varying between 222 and $403 \mathrm{~kg} / \mathrm{m}^{3}$ to replace cement and quartz powder, FGP ranging from 53 to $113 \mathrm{~kg} / \mathrm{m}^{3}$ to replace SF, and GS contents between $25 \%$ to $50 \%$ replacement of QS.

Table 3 UHPGC mixture compositions for various construction applications $\left(\mathrm{Kg} / \mathrm{m}^{3}\right)$

\begin{tabular}{|l|l|l|l|l|l|l|l|}
\hline & \multicolumn{2}{|l|}{ Class A } & \multicolumn{2}{l|}{ Class B } & \multicolumn{2}{l|}{ Class C } & Class D \\
\hline Materials & $\begin{array}{l}\text { UHPG } \\
\text { C-1 }\end{array}$ & $\begin{array}{l}\text { UHPG } \\
\text { C-2 }\end{array}$ & $\begin{array}{l}\text { UHP } \\
\text { GC-3 }\end{array}$ & $\begin{array}{l}\text { UHP } \\
\text { GC-4 }\end{array}$ & $\begin{array}{l}\text { UHPG } \\
\text { C-5 }\end{array}$ & $\begin{array}{l}\text { UHPG } \\
\text { C-6 }\end{array}$ & $\begin{array}{l}\text { UHPG } \\
\text { C-7 }\end{array}$ \\
\hline Water & 196 & 193 & 211 & 186 & 215 & 236 & 224 \\
\hline Cement & 812 & 640 & 608 & 790 & 561 & 739 & 544 \\
\hline Silica fume & 113 & 142 & 158 & 109 & 208 & 205 & 204 \\
\hline $\begin{array}{l}\text { Fine glass } \\
\text { powder }\end{array}$ & 113 & 80 & 53 & 109 & -- & -- & -- \\
\hline $\begin{array}{l}\text { Glass } \\
\text { powder }\end{array}$ & 244 & 382 & 380 & 237 & 411 & 222 & 403 \\
\hline
\end{tabular}

\begin{tabular}{|l|l|l|l|l|l|l|l|}
\hline Quartz sand & 974 & 960 & 684 & 474 & 896 & 443 & 888 \\
\hline Glass sand & -- & -- & 228 & 474 & -- & 443 & -- \\
\hline $\begin{array}{l}\text { Superplastic } \\
\text { izer* }\end{array}$ & 13 & 13 & 10 & 17 & 16 & 10 & 16 \\
\hline PVA fiber & -- & -- & -- & -- & -- & -- & 32.5 \\
\hline Steel fiber & 158 & 158 & 158 & 158 & 158 & 158 & -- \\
\hline
\end{tabular}

\subsection{UHPGC performance}

Table 4 provides the workability and the $f^{\prime} c$ after 2 days of $\mathrm{HC}\left(f^{\prime} c-2 d-H C\right), 28$ days of NC $\left(f^{\prime} c-28 d-N C\right)$, and 91 days of NC $\left(f^{\prime} c-91 d-N C\right)$ of the seven UHPGC mixtures. A mini-slump flow of more than $230 \mathrm{~mm}$ indicates higher concrete workability. Strength results satisfy the requirements given in Table 1. As shown in the table, the mechanical strength for the samples subjected to 2 days of $\mathrm{HC}$ was greater than those obtained under 91-day NC. The concrete mixtures in Class A showed the highest strength results $\left(f^{\prime} c-2 d-H C\right.$ of 210 and $205 \mathrm{MPa}$ for UHPGC-1 and 2, respectively), while those in Class C were the lowest $\left(f^{\prime} c-2 d-H C\right.$ of 169 and $175 \mathrm{MPa}$ for UHPGC-5 and 6, respectively). The concrete in Class B exhibited moderate strength $\left(f^{\prime} c-2 d-H C\right.$ of 200 and 190 $\mathrm{MPa}$ for UHPGC-3 and 4, respectively). UHPGC-7 (Class D) tested at $135 \mathrm{MPa}$ for the $f^{\prime} c-2 d-H C$ due to the inclusion of the PVA fiber.

Table 4 Performance characteristics of UHPGC mixtures used for various construction applications

\begin{tabular}{|c|c|c|c|c|c|c|c|}
\hline & \multicolumn{2}{|c|}{ Class A } & \multicolumn{2}{|c|}{ Class B } & \multicolumn{3}{|c|}{ Class C } \\
\hline Materials & 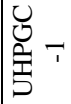 & 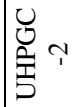 & 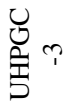 & 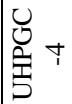 & 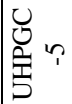 & ○ & $\begin{array}{l}\text { U } \\
\text { 个 } \\
\text { 志 }\end{array}$ \\
\hline Mini-slump flow, $\mathrm{mm}$ & 240 & 230 & 260 & 250 & 270 & 290 & 270 \\
\hline$f^{\prime} c-2 d-H C, \mathrm{MPa}$ & 210 & 205 & 200 & 190 & 169 & 175 & 135 \\
\hline$f^{\prime} c-28 d-N C, \mathrm{MPa}$ & 177 & 170 & 158 & 150 & 130 & 138 & 100 \\
\hline$f^{\prime} c-91 d-N C, \mathrm{MPa}$ & 191 & 185 & 175 & 165 & 155 & 162 & 127 \\
\hline
\end{tabular}

\section{Large-scale field applications}

\subsection{CC and HPC}

The $\mathrm{G}$ concretes (with replacement ratios between $10 \%$ and $30 \%$ by cement content) were used to cast various structure elements in Quebec-Canada between 2006 and 2011 including, interior slabs, exterior slabs (sidewalks), and structural wall elements in various environmental conditions - indoors and outdoors). The performance of samples taken from these concretes and subjected to laboratory curing are presented in references $[11,12]$. The $\mathrm{G}$ used had fineness (retained on $45 \mu \mathrm{m}, \%$ ) $=0 \%$, maximum-particle size $\left(d_{\max }\right)=40 \mu \mathrm{m}$, mean-particle size $\left(d_{50}\right)=12 \mu \mathrm{m}$, Blaine specific surface $=382 \mathrm{~m}^{2} / \mathrm{kg}$, and specific gravity $=2.54$. In addition to the laboratorycured measurements, the long-term evaluation of the Gconcrete performances were conducted by testing core samples (during the concrete life, they exposed to different environmental and service conditions, consolidation, finishing, curing conditions ..etc.). The core results compared to the concrete performances that were initially sampled at the time of casting and 
laboratory cured (ages of 28 and 91 days) are presented in Fig. 5. The results showed improved mechanical and durability properties compared to the reference mixtures. The incorporation of $G$ in concrete contribute to enhancing the microstructure of concrete (densify) especially with age allowing a significant reduction in the pore system and generating higher mechanical and durability properties. The use of $\mathrm{G}$ generates dense $\mathrm{C}-\mathrm{S}$ $\mathrm{H}$ gel rim around the $\mathrm{G}$ particles and densifies the cementitious matrix. The mechanical strength was improved with time due to the pozzolanic activity of $G$ and the microstructure enhancement.

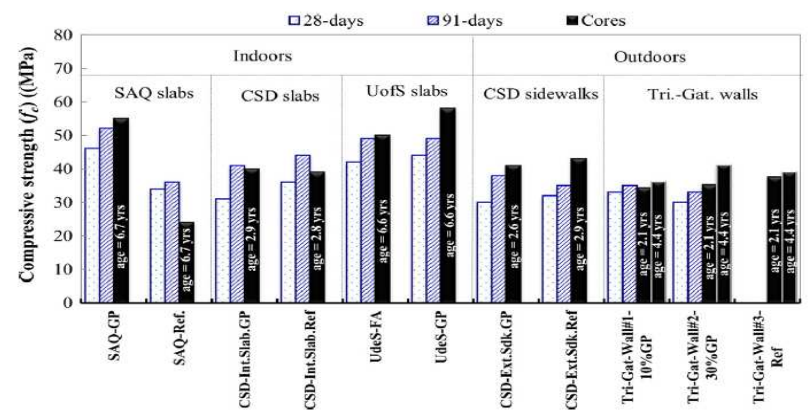

Fig. 5 Compressive strength undertaken on core samplescompared to 28 and 91-days results following casting [14]

\subsection{UHPGC}

The developed UHPGC using $G$ was used in the construction of two footbridges (Fig. 6) at the University of Sherbrooke showing a potential for the UHPGC to be used in future large-scale projects $[13,14]$. The $\mathrm{G}$ used in the UHPGC mix design for constructing the bridges had maximum particle size of $100 \mu \mathrm{m}$ and specific gravity of 2.60. The concrete exhibited excellent workability and rheological properties due to the zero absorption of the glass particles and optimized packing density for the entire concrete matrix. The mechanical properties were found to be excellent allowing reductions in the bridge thickness (material saving), and maintenance costs (due to the excellent durability properties of the UHPGC.

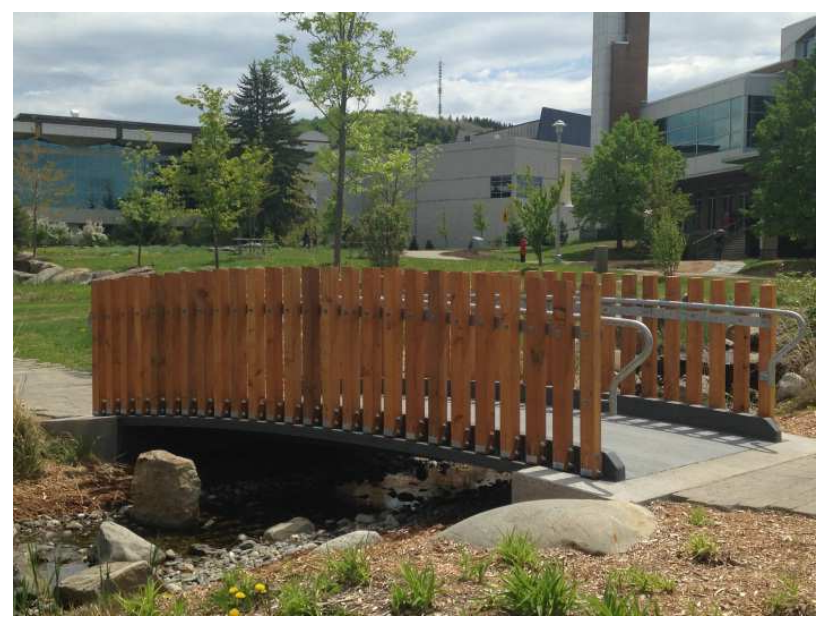

Fig. 6 Picture of a pedestrian bridge in the campus of University of Sherbrooke made of UHPC containing G [10,12]
In order to assess the environmental footprint of a new technology, or product, life cycle assessment (LCA) is a robust and promoted tool. A study carried out by Quantis for Recy-Quebec [15], demonstrated that the valorization of $G$ into concrete shows significant environmental benefits compared to usual end-of-life scenario of landfilling. This valorization project showed even higher environmental benefits from landfilling than being reused as raw material for glass bottle, glass aggregate or glass wool.

The replacement of cement by $\mathrm{G}$ can significantly reduce the carbon footprint of a typical UHPC, as shown in Fig. 7 [10]. The study demonstrated that the use of $\mathrm{G}$ can secure a low carbon footprint while maintaining high strength - which is difficult to obtain with other pozzolanic materials (fly ash, slag, and limestone powder).

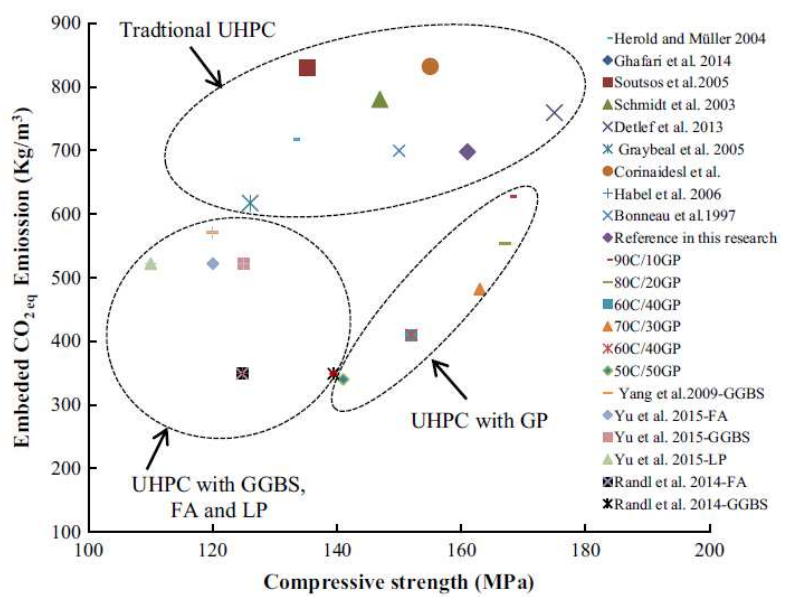

Fig. 7 Relationships between embodied $\mathrm{CO}_{2 \text { eq }}$ for the cement content and 28-day compressive strength under NC [10]

A LCA study by Deschamps et al. [16] compared the environmental life cycle footprint of a conventional UHPC and UHPGC in the case of the pedestrian bridge (Fig 6). For the same concrete volume and service life, results showed that the UHPGC can secure better environmental impacts on all indicators (Fig. 8). It was mainly due to the reduction in cement content with the incorporation of more G. Indeed, cement production appears as a main contributor for most of the environmental indicators of concrete life cycle. It is also important to note that, considering the same volume, UHPGC have a very high environmental impact compared to the conventional concrete. But, considering the volume needed to fulfill the same service life span, UHPGC can reach an environmental impact less important than conventional concrete.

\section{Life cycle assessment}




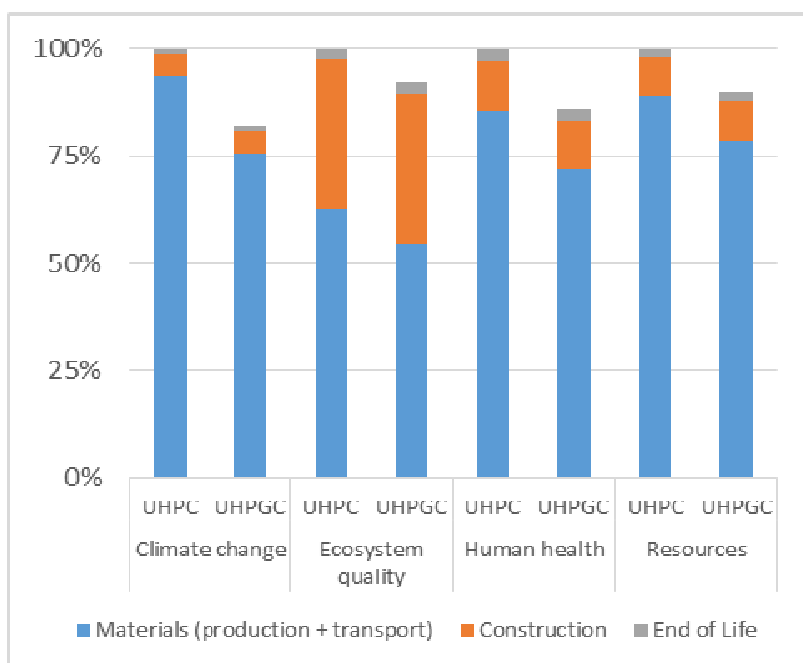

Fig. 8 LCA comparison of UHPC and UHPGC on environmental indicators.

\section{Conclusions}

Based on the previous finding about the use of groundglass pozzolans (G) as a partial replacement of cement in concrete, the following conclusions can be drawn:

$>$ The use of $\mathrm{G}$ increases the workability due to its non-absorption nature and smoothness surface.

> The use of $\mathrm{G}$ can provide better mechanical properties (compressive strength) compared to the reference without $\mathrm{G}$, especially at later ages, provided by the G's pozzolanic activity.

$>$ The use of $\mathrm{G}$ can enhance the durability characteristics (resistance to chloride-ion permeability and resistance to de-icing salt scaling) due to the improved characteristics of the pore network, the filling effect of $\mathrm{G}$ particles, and the conversion of $\mathrm{CH}$ to $\mathrm{C}-\mathrm{S}-\mathrm{H}$. The $\mathrm{G}$ generates dense C-S-H gel rim around the $\mathrm{G}$ particles and densifies the cementitious matrix. This effect is more noticeable at later ages. The $G$ reduces the chloride-ion penetrability of concrete to approximately one third, thereby reducing the risk of chlorideinduced corrosion of steel reinforcement.

> The use of $\mathrm{G}$ can reduce the GHG emission $\left(\mathrm{CO}_{2}\right.$ emissions) of concrete associated with cement production and protecting the environment by favoring the valorization of recyclable materials.

$>$ The use of $\mathrm{G}$ can save the costs related to the processing and the disposing of the waste glass in landfills as well as reducing the price of concrete.

DEED (Leadership in Energy and Environmental Design) certification says, "using glass in concrete can earn double points through the use of by-products, since glass is considered a postconsumption and locally available material while other materials are considered postproduction materials".
$>$ The $\mathrm{G}$ is white color material in the natural state and can provide whitish coloring to the concrete products, leading to better reflectance (Albedo effect).

\section{References}

[1] Zidol, A., Tognonvi, M.T., Tagnit-Hamou, A. (2017) "Effect of glass powder on concrete sustainability, part II", New Journal of Glass and Ceramics, 7, 3447.

[2] Hussain, S.E. and Rasheeduzzafar (1994) Corrosion Resistance Performance of Fly Ash Blended Cement Concrete. ACI Materials Journal, 91, 264-272. http://esatjournals.net/ijret/2012v01/i03/IJRET20120 103042.pdf

[3] Zidol, A. "Optimisation de la finesse de la poudre de verre dans les systèmes cimentaires binaires," Mémoire de maîtrise, Université de Sherbrooke, Qc, Canada, 2009, 168 p.

[4] Aladdine, F. "Propriétés mécaniques et durabilité des bétons incorporant le verre finement broyé," Mémoire de maîtrise, Université de Sherbrooke, Qc, Canada, 2009,124 p.

[5] Zidol, A., Pavoine, A., Tagnit-Hamou, A. (2012) "Effect of glass powder on concrete permeability," International Congress on Durability of Concrete, Trondheim, Norway, June $18-21,2012$.

[6] Jain, J. A. et Neithalath, N. (2010) "Chloride transport in fly ash and glass powder modified concrete. Influence of test methods on microstructure," Cement and Concrete Composites, 32, 2010 p. 148-156.

[7] Houehanou, E., Gagné, R., and Jolin, M. (2010) "Analysis of the representativeness and relative severity of ASTM C672 and NQ 2621-900 standard procedures in evaluating concrete scaling resistance," Canadian Journal of Civil Engineering, 37(11): 1471-1482. doi:10.1139/110-091.

[8] Shayan, A. and Xu, A. (2006) Performance of Glass Powder as a Pozzolanic Material a Field Trial on Concrete Slabs. Cement and Concrete Research, $36,457-468$.

[9] Soliman, N., (2017), "Development of ultra-highperformance concrete (UHPC) using waste glass materials - towards innovative eco-friendly concrete", Doctoral Thesis, Département de génie civil, Faculté de génie, Université de Sherbrooke, $393 \mathrm{pp}$.

[10] Soliman, N. A., and Tagnit-Hamou, A., "Development of Ultra-High-Performance Concrete using Glass Powder - Towards Ecofriendly Concrete," Journal of Building and Construction Materials, Vol. 125, 2016, pp. 600-612.

[11] Omran, A., and Tagnit-Hamou, A., "Performance of Glass-Powder Concrete in Field Applications," Journal of Construction and Building Materials, Vol. 109, 2016, pp. 84-95. 
[12] Omran, A., Morin, E.-D., Harbec, D., and TagnitHamou, A., "Long-Term Performance of GlassPowder Concrete in Large-Scale Field Applications," Journal of Construction and Building Materials, Vol. 135, 2017, pp. 43-58.

[13] Soliman, N., Omran, A. F., and Tagnit-Hamou, A., "Laboratory Characterization and Field Application of Novel Ultra-High Performance Glass Concrete," ACI Materials Journal, Vol. 113, No. 3, 2015, pp. 307-316.

[14] Tagnit-Hamou, A., Soliman, N., Omran, A., Mousa, M., Gauvreau, N., and Provencher, M., "Novel UltraHigh Performance Glass Concrete," Concrete International, Vol. 37, Issue 3, 2015, pp. 41-47.

[15] Quantis, "Analyse environnementale du cycle de vie de projets de commercialisation du verre mixte récupéré via des centres de tri de matières recyclables au Québec", In French, 2015.

[16] Deschamps, J., Tagnit-Hamou, A., Fournier, B., Amor, B., "LCA case study of ultra-high performance concrete with glass powder", International Conference on Cementitious Materials and Alternative Binders for Sustainable Concrete,
Montreal, Canada, October 2-4, 2017. 